\title{
Effects of superficial liming and silicate application on soil fertility and crop yield under rotation
}

\author{
G.S.A. Castro ${ }^{\text {a,* }}$, C.A.C. Crusciol ${ }^{\text {b }}$ \\ a Embrapa Amapá, Juscelino Kubitschek Road, km 5, No 2600 P.O. Box 10, 68903-419, Macapá, AP, Brazil \\ b Department of Crop Science, College of Agricultural Sciences, São Paulo State University (UNESP), José Barbosa de Barros, 1780, P.O. Box 237, 18603-970, Botucatu-SP, Brazil
}

\section{A R T I C L E I N F O}

Article history:

Received 21 June 2011

Received in revised form 5 December 2012

Accepted 11 December 2012

Available online 14 January 2013

\section{Keywords:}

Acidity correction sources

Grain yield

Brazilian 'cerrado'

No-till

\begin{abstract}
A B S T R A C T
Soil acidity and low natural fertility are the main problems for grain production in Brazilian 'cerrado'. Although lime has been the most applied source for soil correction, silicate may be an alternative material due to its lower solubility and Si supply, which is beneficial to several crops. This work aimed to evaluate the efficiency of superficial liming and calcium/magnesium silicate application on soil chemical attributes, plant nutrition, yield components and final yield of a soybean/white oat/maize/bean rotation under no-tillage system in a drywinter region. The experiment was conducted under no tillage system in a deep acid clayey Rhodic Hapludox, Botucatu-SP, Brazil. The design was the completely randomized block with sixteen replications. Treatments consisted of two sources for soil acidity correction (dolomitic lime: $\mathrm{ECC}=90 \%, \mathrm{CaO}=36 \%$ and $\mathrm{MgO}=12 \%$; calcium/magnesium silicate: $\mathrm{ECC}=80 \%, \mathrm{CaO}=34 \%, \mathrm{MgO}=10 \%$ and $\mathrm{SiO}_{2}=22 \%$ ) applied in October 2006 to raise base saturation up to $70 \%$ and a control, with no soil correction. Soybean and white oat were sown in 2006/2007 as the main crop and off-season, respectively. Maize and bean were cropped in the next year (2007/2008). Products from silicate dissociation reach deeper soil layers after 18 months from the application, compared to liming. Additionally, silicate is more efficient than lime to increasing phosphorus availability and reducing toxic aluminum. Such benefits in soil chemical attributes were only evidenced during bean cropping, when grain yield was higher after silicate application comparatively to liming. Both correction sources were improved mineral nutrition of all the other crops, mainly $\mathrm{Ca}$ and $\mathrm{Mg}$ levels and agronomical characteristics, reflecting in higher yield.
\end{abstract}

(c) 2012 Elsevier B.V. All rights reserved.

\section{Introduction}

No tillage currently represents $55 \%$ of the management system applied for grain production in Brazil, which corresponds to 25.5 million ha. Main principles of this production system include no soil mobilization, permanent soil coverage and crop rotation, which contributes to increase residues, decrease pests and diseases and improve input efficiency (Coutinho et al., 2010).

Soil acidity is one of the most yield-limiting factors for crop production. Land area affected by acidity is estimated at 4 billion ha, representing $30 \%$ of the total ice-free land area of the world (Sumner and Noble, 2003). Considering that about $70 \%$ of all agricultural lands in Brazil consist of acid soils, crop yield may be decreased by $\mathrm{Al}$ and $\mathrm{Mn}$ toxicity as well as low exchangeable base availability (Soratto and Crusciol, 2008a). Therefore, soil acidity correction is essential for appropriate crop development. Fageria and Zimmermann (1998) reported that the ideal pH for soybean, bean, maize and wheat growth is around 6.0, which emphasizes the importance of correcting acid soils.

\footnotetext{
* Corresponding author. Tel.: +55 9640099562.

E-mail address: gsacastro@hotmail.com (G.S.A. Castro).
}

Lime is the most applied source for acidity correction in Brazil due to its price and capacity to increase fertilizer efficiency. Nevertheless, lime is not a very soluble material and its dissociated components show limited mobility, usually restricting correction effects in uppermost soil layers, mainly under non-mobilized conditions of no tillage (Soratto and Crusciol, 2008b).

However, other materials may be applied for acidity correction, as long as the product is constituted by neutralizing components such as calcium and/or magnesium oxides, hydroxides, carbonates and silicates. Calcium and magnesium silicates are similar to carbonates in composition; so, those sources can potentially replace lime even more advantageously (Carvalho-Pupatto et al., 2004; Ramos et al., 2006). Recommendation for silicate application can be based on any methods of lime requirement (Korndörfer et al., 1999).

According to Alcarde and Rodella (2003), calcium silicate is 6.78 times more soluble than lime, being a good option for superficial application in no tillage system (Carvalho-Pupatto et al., 2004). Some advantages of silicate include higher reaction rate and mobility down to deeper soil layers. Also, silicon, which is a beneficial element, is supplied in soil. Si deposition decreases water losses through evapotranspiration (Ma and Yamaji, 2006), increases tolerance to pests (Goussain et al., 2002) and diseases (Berni and Prabhu, 2003), heavy 
metals and toxic aluminum (Prabagar et al., 2011) and lodging. Plants become more erect and photosynthetic efficiency is improved (Pulz et al., 2008).

Si supply may improve crop yield stability as a consequence of biotic and abiotic stress tolerance such as water deficit, once almost all grain-producing regions in Brazil are liable to drought, mainly in 'cerrado'. Compared to lime, there are fewer studies on superficial application of silicate as an acidity correction source for grain production in no-till. Field research on slag application, which contains appropriate levels of calcium silicate as neutralizing component, indicate this source can be more efficient than other materials (limestone, aqueous lime and sewage sludge) for correction of deeper soil layers due to their higher solubility (Corrêa et al., 2007, 2008).

This work aimed to evaluate the efficiency of superficial liming and silicate application on soil chemical attributes, plant nutrition, yield components and final yield of a soybean/white oat/maize/bean rotation under no-tillage system in a dry-winter region.

\section{Material and methods}

The experiment was conducted in two seasons, between October 2006 and July 2008, at Lageado Experimental Farm, College of Agricultural Sciences, FCA/UNESP, in Botucatu, São Paulo State, Brazil. Geographical coordinates are $48^{\circ} 23^{\prime} \mathrm{W}, 22^{\circ} 51^{\prime} \mathrm{S}$ and $765 \mathrm{~m}$ asl. Soil in the area is a deep acid clayey Rhodic Hapludox (FAO, 2006). According to Köeppen's classification, climate is Cwa, which corresponds to tropical altitude with dry winter and hot wet summer.

During the experiment, rainfall and monthly average temperature were, respectively: 2006: $66 \mathrm{~mm}$ and $23.0{ }^{\circ} \mathrm{C}$ in October, $175 \mathrm{~mm}$ and $23.5^{\circ} \mathrm{C}$ in November, $275 \mathrm{~mm}$ and $23.3^{\circ} \mathrm{C}$ in December; 2007: $410 \mathrm{~mm}$ and $23.0^{\circ} \mathrm{C}$ in January, $108 \mathrm{~mm}$ and $24.1{ }^{\circ} \mathrm{C}$ in February, $49 \mathrm{~mm}$ and $24.8{ }^{\circ} \mathrm{C}$ in March, $40 \mathrm{~mm}$ and $22.8^{\circ} \mathrm{C}$ in April, $42 \mathrm{~mm}$ and $18.5{ }^{\circ} \mathrm{C}$ in May, $23 \mathrm{~mm}$ and $19.8{ }^{\circ} \mathrm{C}$ in June, $172 \mathrm{~mm}$ and $17.9{ }^{\circ} \mathrm{C}$ in July, $0 \mathrm{~mm}$ and $20.4{ }^{\circ} \mathrm{C}$ in August, $10 \mathrm{~mm}$ and $23.1{ }^{\circ} \mathrm{C}$ in September, $77 \mathrm{~mm}$ and $23.9{ }^{\circ} \mathrm{C}$ in October, $177 \mathrm{~mm}$ and $22.0{ }^{\circ} \mathrm{C}$ in November, $280 \mathrm{~mm}$ and $22.8^{\circ} \mathrm{C}$ in December; 2008: $378 \mathrm{~mm}$ and $22.5^{\circ} \mathrm{C}$ in January, $94 \mathrm{~mm}$ and $23.5^{\circ} \mathrm{C}$ in February, $60 \mathrm{~mm}$ and $23.0{ }^{\circ} \mathrm{C}$ in March, $102 \mathrm{~mm}$ and $21.6{ }^{\circ} \mathrm{C}$ in April, $40 \mathrm{~mm}$ and $18.3{ }^{\circ} \mathrm{C}$ in May, $20 \mathrm{~mm}$ and $17.6{ }^{\circ} \mathrm{C}$ in June, $0 \mathrm{~mm}$ and $19.1{ }^{\circ} \mathrm{C}$ in July.

Before the experiment was installed, chemical attributes were determined (0-20 cm) according to Raij et al. (2001). Results were: organic matter: $18.25 \mathrm{~g} \mathrm{dm}^{-3}$; $\mathrm{pH}\left(\mathrm{CaCl}_{2}\right): 4.2$; $\mathrm{P}$ (resin): $3.62 \mathrm{mg} \mathrm{dm}^{-3} ; \mathrm{K}$, $\mathrm{Ca}, \mathrm{Mg}$ and CEC: $0.76,11.62,5.75$ and $74.98 \mathrm{mmol}_{\mathrm{c}} \mathrm{dm}^{-3}$, respectively; and base saturation: $24.2 \%$.

The experimental design was the completely randomized block with sixteen replications. Treatments $(5.4 \times 10-\mathrm{m}$ plots $)$ consisted of two sources for soil acidity correction (dolomitic lime: ECC $=90 \%$, $\mathrm{CaO}=36 \%$ and $\mathrm{MgO}=12 \%$; calcium/magnesium silicate: $\mathrm{ECC}=80 \%$, $\mathrm{CaO}=34 \%, \mathrm{MgO}=10 \%$ and $\mathrm{SiO}_{2}=22 \%$ ) and a control, with no soil correction.

Rates were calculated to raise base saturation up to $70 \%$. In October 2006, 3.8 Mg ha ${ }^{-1}$ of dolomitic lime and $4.1 \mathrm{Mg} \mathrm{ha}^{-1}$ of calcium/magnesium silicate were applied over previously desiccated (1800 g ha ${ }^{-1}$ of glyphosate) millet residues $\left(4 \mathrm{Mg} \mathrm{ha}^{-1}\right)$.

Soybean (Glycine max (L.) Merril) cultivar Embrapa 48 was sown on November 29th 2006 at $0.45-\mathrm{m}$ row spacing and 22 seeds- $\mathrm{m}^{-1}$ rate. This intermediate maturation-cycled genotype is highly demanding for soil fertility. Seeds were treated with fungicide (vitavax + thiram $50+50 \mathrm{~g}$ of the active ingredient every $100 \mathrm{~kg}$ of seeds) and inoculant (Bradyrhizobium japonicum). Base fertilization consisted of $250 \mathrm{~kg} \mathrm{ha}^{-1}$ of 04-20-20 NPK formula, according to Raij et al. (1997).

Soybean full flowering took place 45 days after seedling emergence. At that stage, 10 plants were sampled for dry matter evaluation. Also, the 3rd leaf with the petiole from 30 plants was sampled per plot (Raij et al., 1997) for macronutrient (N, P, K, Ca, Mg and S) and Si diagnosis. Soybean was harvested on April 3rd 2007 and samples were taken for the evaluation of yield components (plant population, number of pods per plant, number of grains per pod and mass of 100 grains) and final yield (13\% moisture content).

Soon after soybean harvest, on April 10th 2007, white oat (Avena sativa L.) cultivar 'IAC 7 ' was sown at 0.45 -m row spacing and density of 133 viable seeds per $\mathrm{m}^{2}$. Although base fertilization was not carried out, $40 \mathrm{~kg} \mathrm{ha}{ }^{-1}$ of $\mathrm{N}$ as urea was applied 30 days after seedling emergence. Full flowering of plants took place 50 days after sowing. At that stage, 10 plants were sampled for dry matter evaluation. Also, the flag leaf of 50 plants per plot was sampled (Raij et al., 1997) for macronutrient ( $\mathrm{N}, \mathrm{P}, \mathrm{K}, \mathrm{Ca}, \mathrm{Mg}$ and $\mathrm{S}$ ) and $\mathrm{Si}$ diagnosis. White oat was harvested on July 30th 2007 and yield components (number of panicles per $\mathrm{m}^{2}$, number of grain-filled spikelets per panicle mass of 1000 grains) and final yield (13\% moisture content) were determined.

Maize (Zea mays L.) was sown on December 2nd 2007 at 0.45-m row spacing and 3 seeds- $\mathrm{m}^{-1}$ rate. The hybrid chosen was the intermediate maturation-cycled 2B570 demanding for soil fertility. Seeds were treated with fungicide (vitavax + thiram $-50+50 \mathrm{~g}$ of the active ingredient every $100 \mathrm{~kg}$ of seeds). Base fertilization consisted of $300 \mathrm{~kg} \mathrm{ha}^{-1}$ of the 08-28-16 NPK formula (Raij et al., 1997). Side dressing fertilization took place on January 10th 2008 and consisted of $90 \mathrm{~kg} \mathrm{ha}^{-1}$ of $\mathrm{N}$, applied mechanically between rows as urea.

Full flowering of maize plants occurred 64 days after seedling emergence. At that stage, 10 plants per plot were sampled for dry matter evaluation. Also, the central third part of 30 leaves was sampled at ear base (Raij et al., 1997) for macronutrient (N, P, K, Ca, Mg and S) and Si diagnosis. Harvest took place on April 1st 2008 and sampling was carried out to evaluate yield components (plant population, ear index, number of grains per ear and mass of 100 grains) and final yield (13\% moisture content).

On April 5th 2008, bean (Phaseolus vulgaris L.) cultivar 'Pérola' was sown at $0.45-\mathrm{m}$ row spacing and density of 18 seeds per $\mathrm{m}^{2}$. Although base fertilization was not carried out, $40 \mathrm{~kg} \mathrm{ha}^{-1}$ of $\mathrm{N}$ as urea was applied 20 days after seedling emergence. Full flowering of plants took place 47 days after sowing. At that stage, 10 plants were sampled for dry matter evaluation. Also, the 3rd leaf with the petiole from 30 plants was sampled per plot (Raij et al., 1997) for macronutrient (N, $\mathrm{P}, \mathrm{K}, \mathrm{Ca}, \mathrm{Mg}$ and S) and Si diagnosis. Plants were harvested on June 29th 2008 and yield components (plant population, number of pods per plant, number of grains per pod and mass of 100 grains) and final yield (13\% moisture content) were evaluated.

Phytosanitary measures were taken based on recommendations and requirements for each crop. Efficiency use of fertilizers was calculated for each treatment by dividing the sum of soybean, white oat, maize and bean yields by the total amount of fertilizers applied in all crops.

Biomass sampled at full flowering was dried in oven at $65{ }^{\circ} \mathrm{C}$ until constant weight. Afterwards, leaves were grounded and chemically evaluated as for macronutrient (N, P, K, Ca, Mg and S) and Si levels, according to Malavolta et al. (1997) and Korndörfer et al. (1999), respectively.

Soil chemical characteristics ( $\mathrm{pH}$, organic matter, $\mathrm{H}^{+}$and $\mathrm{Al}, \mathrm{P}, \mathrm{K}, \mathrm{Ca}$, $\mathrm{Mg}, \mathrm{Al}^{3+}$ and Si) were evaluated 6 (April 2007), 12 (October 2007) and 18 months (April 2008) after the application of correction materials at depths of $0.00-0.05,0.05-0.10,0.10-0.20,0.20-0.40$ and $0.40-0.60 \mathrm{~m}$. Six simple samples were taken at random from the useful area of each plot and between rows of the previous crop to form a composite sample. Those were dried, sieved (2-mm sieves) and analyzed according to Raij et al. (2001) and Korndörfer et al. (1999).

Data was submitted to variance analysis by the $F$ test $(p<0.05)$ and means were compared by the test (LSD) $(\mathrm{p}<0.05)$.

\section{Results and discussion}

According to Fig. 1, both correction sources increased $\mathrm{pH}$ in the uppermost soil layer. After 12 months from their application, liming 

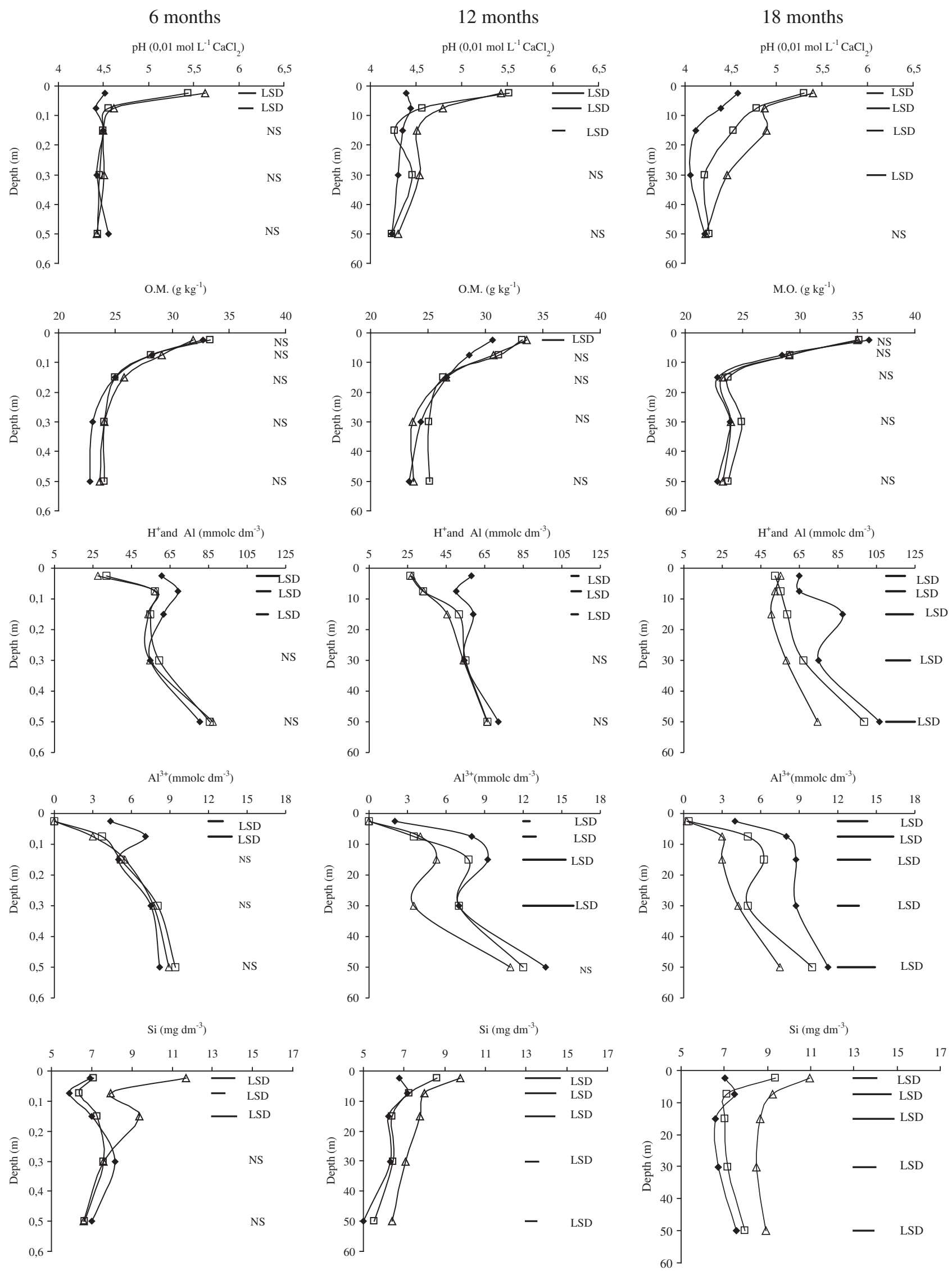

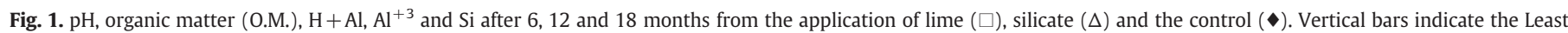
Significant Difference (LSD). 
Table 1

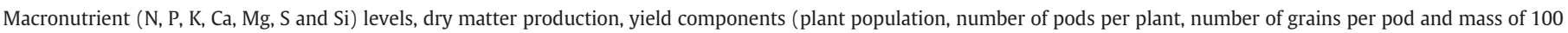
grains) and soybean yield affected by superficial liming and silicate application under no tillage system. Botucatu-SP, Brazil, 2006-2008.

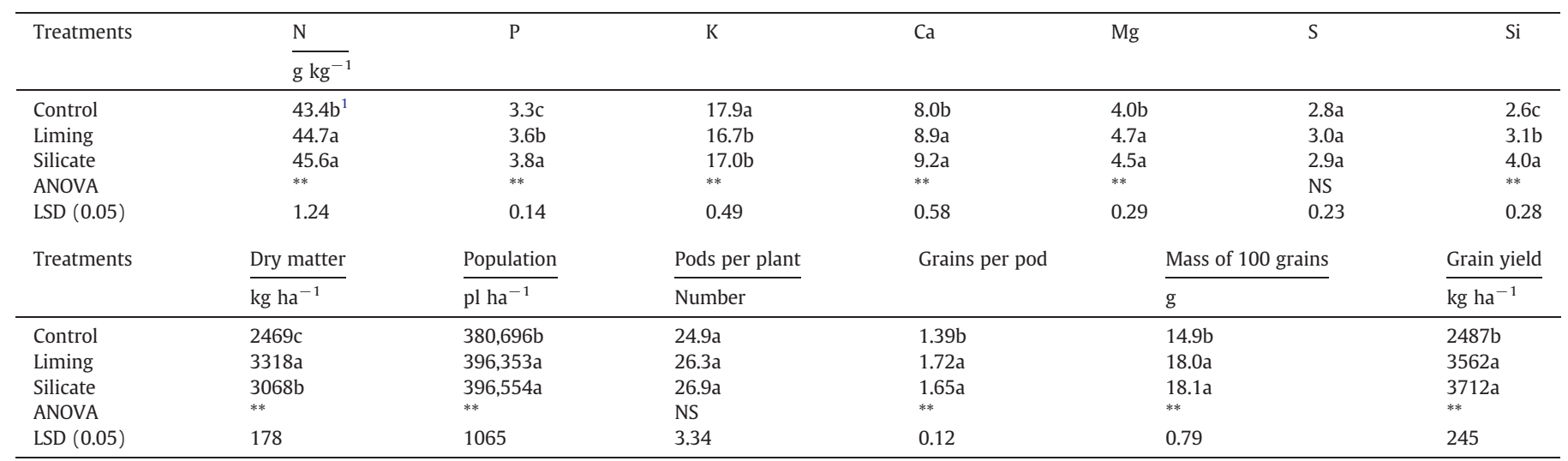

* and ${ }^{* *}$ significant at probability levels of 5 and $1 \%$, respectively by the F test; NS: non-significant.

1 Means followed by different letters in the column differ statistically by the t test $(\mathrm{p}<0.05)$.

effects had only influenced $\mathrm{pH}$ down to $0.05 \mathrm{~m}$, while silicate increased $\mathrm{pH}$ at $0.10-0.20-\mathrm{m}$ depth. Effects of soil correction after 18 months were observed down to 0.40 and $0.20 \mathrm{~m}$ after silicate and lime application, respectively. Corrêa et al. (2007) found that $\mathrm{pH}$ was increased by slag application down to $0.40 \mathrm{~m}$ after 15 months, whereas liming effects were confined down to $0.10 \mathrm{~m}$.

Hydroxyl concentration is increased and $\mathrm{H}^{+}$concentration in soil solution is decreased by the application of materials for acidity correction, consequently increasing soil pH (Oliveira and Pavan, 1996). Liming recommendations take into account full incorporation of correction sources in soil to maximizing their beneficial effects.

Many studies about no-till have shown that superficial liming effects on correction of subsuperficial soil layers depend on product dose and textural properties, application method, soil type, climate (especially rainfall), tillage system and time after the application (Oliveira and Pavan, 1996; Rheinheimer et al., 2000; Soratto and Crusciol, 2008a,b). Due to all those factors, correction efficiency is variable, particularly whenever applied for subsuperficial correction.

Compared to lime, silicate is more efficient in correcting acidity down the profile due to its higher solubility (Alcarde and Rodella, 2003). As silicate reaction is faster in uppermost soil layers, an alkalinization front is formed to correct acidity of deeper layers in a shorter period of time.

Soil organic matter (Fig. 1) was only affected by the application of correction sources after 12 months. Both materials increased organic matter levels down to $0.05 \mathrm{~m}$ possibly due to higher dry matter production by soybean and white oat (Tables 1 and 2). Liming and silicate application increased residue supply on soil surface and, probably, root production. However, treatments did not influence dry matter after 18 months. It is possible that higher $\mathrm{pH}$ had also increased microbial activity and improved organic matter mineralization (Fuentes et al., 2006). After 6 and 12 months from their application, both sources decreased $\mathrm{H}^{+}$and Al levels down to $0.20 \mathrm{~m}$ (Fig. 1), although silicate had been more efficient from 0.10 to $0.20 \mathrm{~m}$. Lime and silicate effects after 18 months were noticed down to 0.20 and $0.60 \mathrm{~m}$, respectively. Correction sources have distinct solubility properties. Once silicate is more soluble than lime, dissociation rate is faster and may affect ion mobility down the profile. Soratto and Crusciol (2008a) observed that superficial liming decreased $\mathrm{H}^{+}$and Al levels at depths of $0.05-0.10-\mathrm{m}$ and $0.10-0.20 \mathrm{~m}$ after 6 and 12 months from the application, respectively. The decrease of $\mathrm{H}^{+}$and $\mathrm{Al}$ values occurs by increasing the concentration of hydroxyl in the soil, resulting from lime application, in which a

Table 2

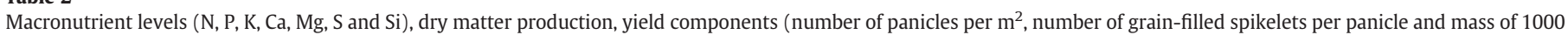
grains) and white oat yield affected by superficial liming and silicate application under no tillage system. Botucatu-SP, Brazil, $2006-2008$.

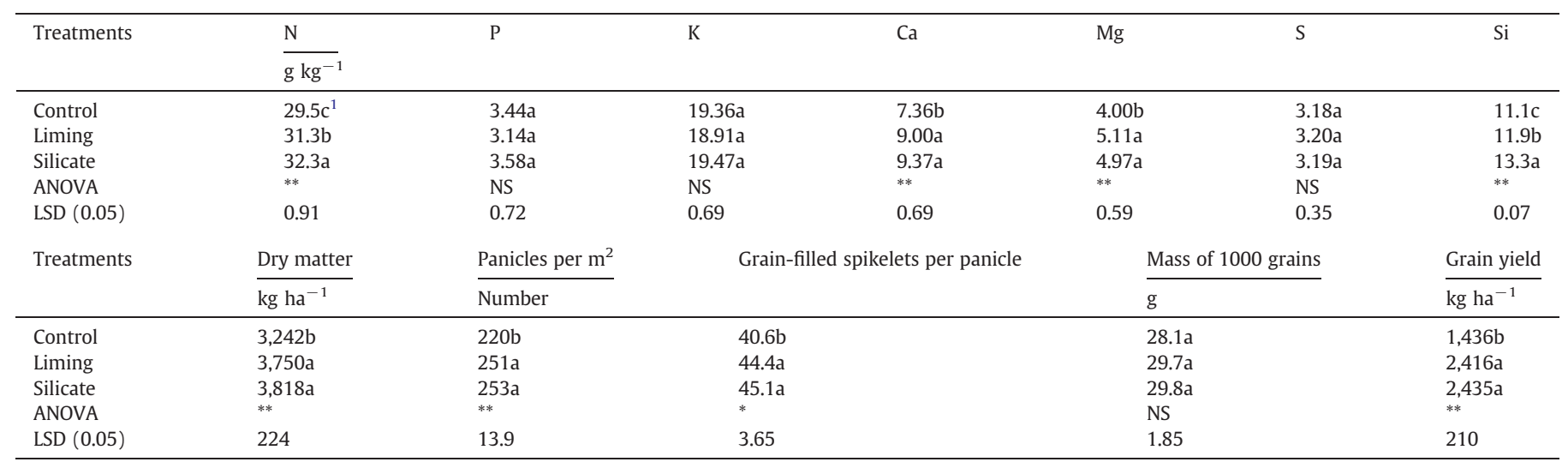

* and ${ }^{* *}$ significant at probability levels of 5 and $1 \%$, respectively by the F test; NS: non-significant.

${ }^{1}$ Means followed by different letters in the column differ statistically by the test $(\mathrm{p}<0.05)$. 

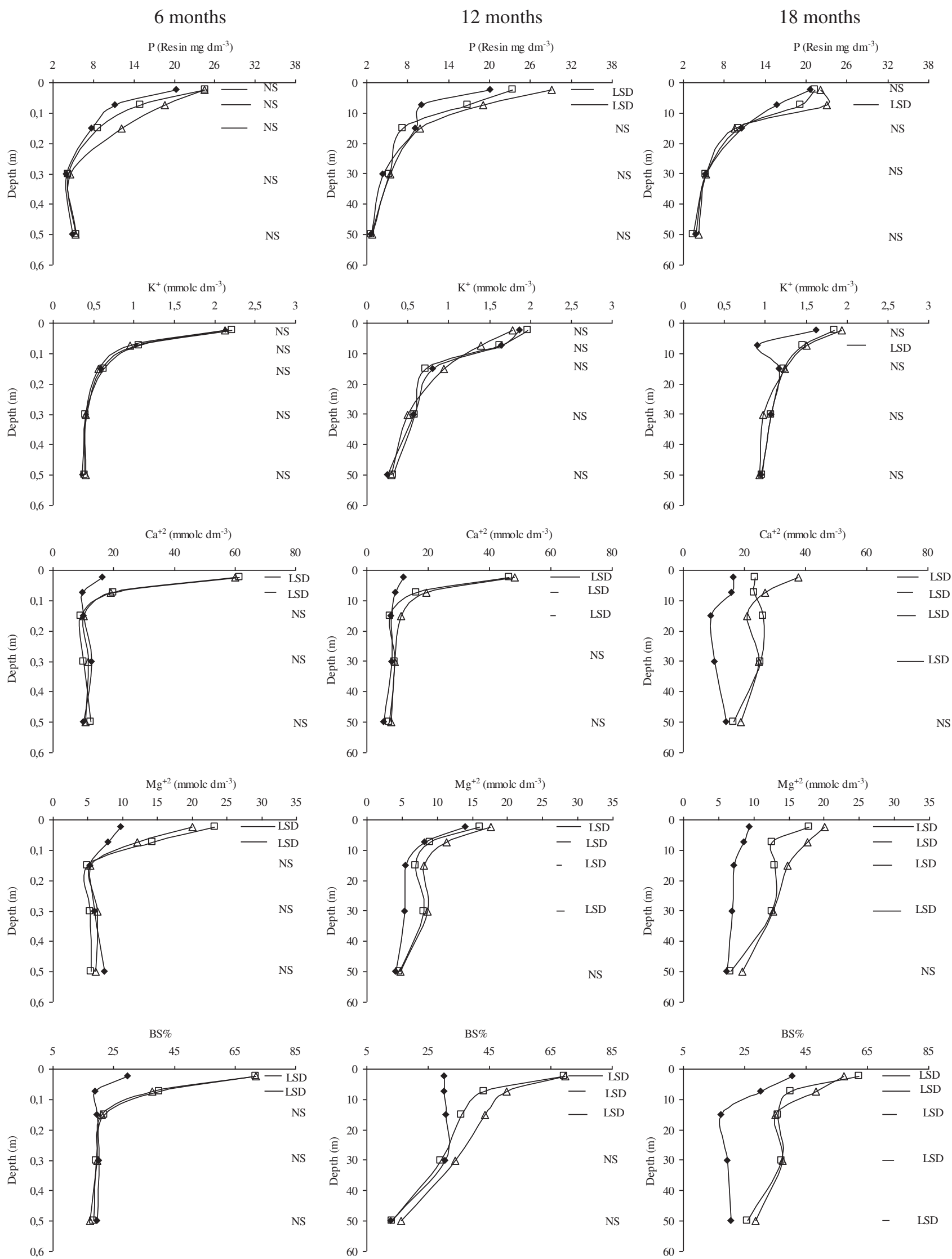

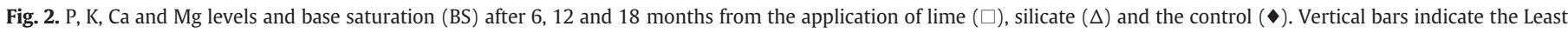
Significant Difference (LSD). 
fraction of these hydroxyl reacts with the excess of $\mathrm{H}^{+}$in solution, increasing the soil $\mathrm{pH}$, and the remainder of these promotes the aluminum precipitation in $\mathrm{Al}(\mathrm{OH})_{3}$, which one is non-toxic to plants (Oliveira and Pavan, 1996).

After 6 months, $\mathrm{Al}^{3+}$ levels were decreased by both materials from 0.05 to $0.10 \mathrm{~m}$ (Fig. 1). Nevertheless, silicate reduced $\mathrm{Al}^{3+}$ down to $0.40 \mathrm{~m}$ after 12 months while liming effects were still only observed in the $0.05-0.10-\mathrm{m}$ depth. By the 18th month, silicate and lime had decreased $\mathrm{Al}$ toxicity down to 0.60 and $0.40 \mathrm{~m}$, respectively, differing from the control. It is also important to mention that soil correction reduced $\mathrm{Al}^{3+}$ to zero in the uppermost soil layer in all evaluation times.

$\mathrm{Al}^{3+}$ levels can be both decreased by increasing $\mathrm{pH}$ (CarvalhoPupatto et al., 2004) or by reactions with Si and later precipitation as hydroxoaluminosilicate, which reduces its availability (Exley, 1998). Silicate application increased Si levels down to $0.20 \mathrm{~m}$ after 6 months and in all soil depths after 12 and 18 months, corroborating CarvalhoPupatto et al. (2004) and Corrêa et al. (2007). On the other hand, liming increased Si levels at the depth of 0.00-0.05 m after 12 and 18 months from the application. This result may be attributed to solubilization of silica compounds as $\mathrm{pH}$ increases or reduced capacity of Si bonds to colloid sorption sites, increasing its concentration in soil solution (Pulz et al., 2008).

Both sources increased P levels down to $0.05 \mathrm{~m}$ after 6 months from their application (Fig. 2). Nevertheless, silicate additionally increased P levels deep from 0.05 to $0.20 \mathrm{~m}$, differing from the control. After 12 months, P was increased by acidity correction in the $0.05-$ 0.10 -m depth, but only in the uppermost layer silicate was more efficient than lime. Only silicate effects persisted until the 18th month, increasing P levels from 0.05 to $0.10 \mathrm{~m}$.

Besides hydroxyl concentration and ionic activity in soil solution, $\mathrm{pH}$ also increases $\mathrm{Fe}$ and $\mathrm{Al}$ precipitation. On the other hand, low-soluble $\mathrm{P}-\mathrm{Fe}$ and $\mathrm{P}-\mathrm{Al}$ precipitation are reduced. Also, negative charges are generated by $\mathrm{OH}^{-}$deprotonation and exposed by clays and organic matter. That way, phosphate is repelled by the adsorption surface (Mcbride, 1994), releasing P into soil solution. That is why both materials for acidity correction are capable of increasing $\mathrm{P}$ availability. Nevertheless, better results of silicate application are attributed to the competition between Si and P for the same sorption sites of soil colloids, increasing P availability to plants (Pulz et al., 2008). Those $P$ sites are saturated or blocked by the silicate anion, improving efficiency of P fertilization.

$\mathrm{K}^{+}$levels (Fig. 2) were not affected by the treatments in the first two evaluation times. However, both sources increased $\mathrm{K}^{+}$levels after 18 months, but only in the $0.05-0.10-\mathrm{m}$ depth. Direct effects of soil correction on $\mathrm{K}$ levels in soil are still a controversial subject. Even so, Flora et al. (2007) reported better K availability after liming as a result of reduced leaching. According to the same authors, soil correction increases $\mathrm{pH}$ and negative charges in the uppermost soil layer, where $\mathrm{K}^{+}$ions are adsorbed. Acidity correction sources decrease $\mathrm{K}$ mobility proportionally to soil depth that is corrected (Flora et al., 2007). Besides, $\mathrm{K}$ increase after 18 months may be related to ion leaching from plant tissues (Rosolem et al., 2007), once soil correction increased dry matter production (Tables 1,2 and 3) and accumulated more $\mathrm{K}$ in shoots.

Silicate application increased Ca levels (Fig. 2) and differed from liming at depths of 0.10-0.20 and 0.00-0.05 m after 12 and 18 months, respectively. In both cases, liming was not statistically different from the control. In general, a leaching front of Ca was observed as time went by. After 6,12 and 18 months from lime and silicate application, correction effects were found down to $0.10,0.20$ and $0.40 \mathrm{~m}$, respectively, corroborating with Corrêa et al. (2007) and Soratto and Crusciol (2008a).

Similarly to $\mathrm{Ca}, \mathrm{Mg}$ levels were increased by soil correction down to $0.10 \mathrm{~m}$ after 6 months (Fig. 2). Twelve months after the application, liming increased $\mathrm{Mg}$ levels only in the $0.20-0.40-\mathrm{m}$ depth once ions had possibly been leached from superficial to deeper layers. Also, Mg levels in the control had been increased through nutrient cycling by soybean and white oat. Still considering this evaluation period, silicate increased $\mathrm{Mg}$ levels down to $0.40 \mathrm{~m}$; this same effect was noticed after 18 months from the application of both correction sources, although silicate had increased $\mathrm{Mg}$ availability more efficiently than lime from 0.05 to $0.10 \mathrm{~m}$.

Ca and $\mathrm{Mg}$ intense leaching may be related to formation of inorganic ionic pairs with $\mathrm{NO}_{3}^{-}, \mathrm{HCO}_{3}^{-}, \mathrm{OH}^{-}$(Rheinheimer et al., 2000), $\mathrm{Cl}^{-}$and $\mathrm{SO}_{4}^{2-}$ (Caires et al., 2006) from mineral fertilization or from crop production stability, leading to cation dislocation and leaching down the profile.

Effects of soil correction on $\mathrm{H}^{+}$and $\mathrm{Al}, \mathrm{Ca}$ and $\mathrm{Mg}$ levels reflected on base saturation (Fig. 2). Significant variations were found down to $0.10,0.20$ and $0.60 \mathrm{~m}$ after 6,12 and 18 months from correction, respectively. Silicate differed from lime at depths of $0.10-0.20 \mathrm{~m}$ and 0.05-0.10-m after 12 and 18 months from their application, respectively. Corrêa et al. (2007) found similar results.

It is important to mention that $\mathrm{pH}$ and base saturation variations as well as mobility of basic cations down the profile depend on the absence of acid cations in superficial soil layers, which are bound preferably. According to Rheinheimer et al. (2000), this can be observed in $\mathrm{pH}\left(\mathrm{H}_{2} \mathrm{O}\right)$ between 5.2 and 5.5 . Mobility of basic cations $\left(\mathrm{K}^{+}, \mathrm{Ca}^{2+}\right.$ and $\left.\mathrm{Mg}^{2+}\right)$ is hindered by their adsorption to variable negative charges increased by pH (Caires et al., 2006). Therefore, mobility

Table 3

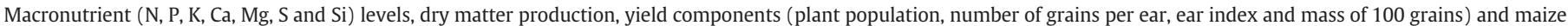
yield affected by superficial liming and silicate application under no tillage system. Botucatu-SP, Brazil, 2006-2008.

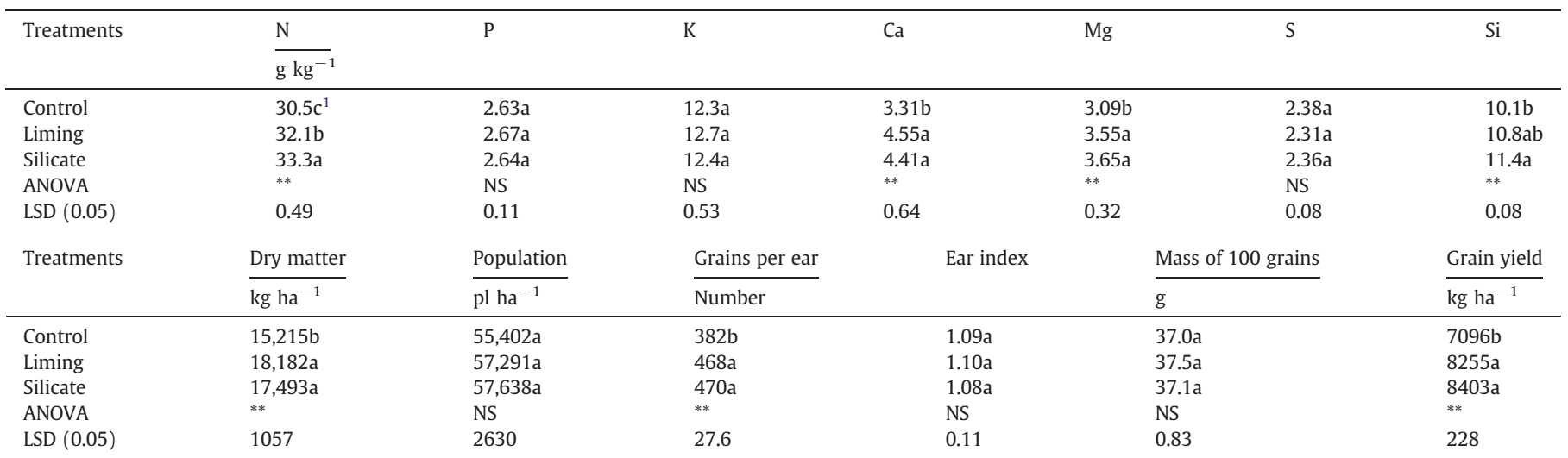

* and ${ }^{* *}$ significant at a probability level of 5 and $1 \%$, respectively by the F test; NS: non-significant.

1 Means followed by different letters in the column differ statistically by the test $(\mathrm{p}<0.05)$. 
may have been favored by formation of ionic pairs between cations and inorganic compounds. Those may be originated from the dissociation of correction sources or anions released through root exudation in rhizosphere such as $\mathrm{OH}^{-}$and $\mathrm{HCO}^{3-}$ as well as nitrate $\left(\mathrm{NO}_{3}^{-}\right)$, sulfate $\left(\mathrm{SO}_{4}^{2-}\right)$ and chloride $\left(\mathrm{Cl}^{-}\right)$from fertilizer mineralization or residue decomposition on soil surface (Rosolem et al., 2007). Organic ionic pairs formed by soil cations and water-soluble compounds with low molecular weight (originated from residue decomposition through $\mathrm{C}=\mathrm{O}-\mathrm{OH}$ radicals) may also improve ion mobility down the profile (Franchini et al., 2003).

Macronutrient levels in leaves (Table 1) were within the range considered appropriate for soybean development (Raij et al., 1997). Only S levels were not affected by the treatments. Soil correction increased $\mathrm{N}$, $\mathrm{P}, \mathrm{Ca}, \mathrm{Mg}$ and Si levels compared to the control, although silicate had been more efficient to increasing $\mathrm{P}$ and $\mathrm{Si}$ levels comparatively to lime. Both sources reduced $\mathrm{K}$ levels compared to the control.

Caires et al. (2006) also reported $\mathrm{N}$ availability increased by soil correction. The authors explained that low soil acidity leads to increasing activity of nitrogen-fixing bacteria. Caires et al. (2006) reported reduced $\mathrm{K}$ levels in maize tissues and increased levels of $\mathrm{Ca}$ and $\mathrm{Mg}$ after superficial liming. The authors explained that the results based on competition among $\mathrm{K}, \mathrm{Ca}$ and $\mathrm{Mg}$.

A correlation between $P$ and Si levels was found in soybean, similarly to soil results. According to Fig. 1, higher $\mathrm{pH}$ is related to $\mathrm{P}$ uptake by crops (Mcbride, 1994), increasing P levels after soil correction. P levels in leaves increased by silicate application may be associated to competition between silicate $\left(\mathrm{H}_{3} \mathrm{SiO}_{4}^{-}\right)$and phosphate $\left(\mathrm{H}_{2} \mathrm{PO}_{4}^{-}\right)$for the same sorption sites (Fig. 2). Pulz et al. (2008) also observed higher P availability in soil and in potato plants after silicate application compared to lime. Barcelo et al. (1993) showed that high concentrations of Si reduce stress caused by high concentration of aluminum, limiting factor in crop development.

Superficial liming is known to positively influence Ca and Mg nutrition in soybean and maize cropped under consolidated no-till, once lime dissociation products also reach a large area explored by plant roots (Caires et al., 2006).

Dry matter production, yield components and grain yield were significantly influences by the treatments (Table 1 ). Soil correction increased shoot dry matter, evaluated at flowering, compared to the control, although lime effects had been more accentuated than silicate. Soil correction improved soil fertility (Figs. 1 and 2) and thus plant nutrition, leading to better plant development (Table 1). So, both liming and silicate application increased grain yield by $43.2 \%$ and $49.3 \%$ as a result of higher plant population, number of grains per pod and mass of 100 grains (Table 1 ).
Similarly, Corrêa et al. (2008) studied superficial liming and silicate applied as slag and observed that both of them increased yield components individually and, consequently, soybean final yield.

Excepting K, macronutrient levels (Table 2) were within the appropriate range established by Raij et al. (1997) for white oat. Both correction sources increased $\mathrm{N}, \mathrm{Ca}, \mathrm{Mg}$ and $\mathrm{Si}$ levels compared to the control, although silicate effects had been more efficient in increasing $\mathrm{N}$ and Si than lime. Although P availability in soil had been increased by soil correction (Fig. 1), levels in leaves were not influenced possibly due to residual effects of soybean fertilization. $\mathrm{K}$ levels did not vary, similarly to soil results. Caires et al. (2002) did not observe significant influence of superficial liming on wheat nutrition under no-till in Southern Brazil. In this experiment, $\mathrm{N}$ levels were increased by soil correction as a consequence of $\mathrm{N}$ accumulation and cycling by previous soybean cropping (Table 1 ). Ca, $\mathrm{Mg}$ and Si results are related to higher levels in soil (Figs. 1 and 2).

Soratto and Crusciol (2008b) reported that liming increased Ca and reduced $\mathrm{Mg}$ levels in black oat leaves as $\mathrm{Ca}: \mathrm{Mg}$ ratio was higher.

Treatments influenced white oat dry matter, yield components and grain yield (Table 2). Soil correction increased shoot dry matter compared to the control due to better $\mathrm{N}, \mathrm{Ca}, \mathrm{Mg}$ and $\mathrm{Si}$ nutrition (Table 2). Besides, it is possible that base leaching after soil correction (Fig. 1), especially Ca, had been favored root growth in deeper soil layers as well as water and nutrient uptake during drought periods (Caires et al., 2002; Soratto and Crusciol, 2008b).

Few studies in literature emphasize the effects of liming on white oat yield components. Nevertheless, this research showed that both correction sources increased the number of panicles per area, grain-filled spikelets per panicle and, consequently, grain yield (Table 2). Weight of 1000 grains was not influeced by the treatments. Both liming and silicate application increased grain yield by $68.2 \%$ and $69.6 \%$, respectively. Soratto and Crusciol (2008b) also reported that liming increased the number of panicles per $\mathrm{m}^{2}$, grain-filled spikelets per panicle and black oat final yield.

Nutrient levels in maize leaves (Table 3) were consistent with those cited by Raij et al. (1997) for appropriate plant development. The application of both materials increased N, Ca and Mg levels. Silicate application increased Si levels compared to the control, but not differing from liming. Maize was cropped between the evaluations conducted after 12 and 18 months from the application of correction sources. This period corresponded to better soil fertility conditions and reflected in higher dry matter production (Table 3 ). Therefore, both lime and silicate increased the number of grains per ear and, consequently, final yield by $16.3 \%$ and $18.4 \%$, respectively, compared to the control (Table 3).

Table 4

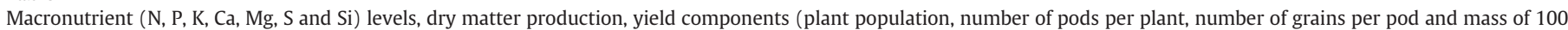
grains) and bean yield affected by superficial liming and silicate application under no tillage system. Botucatu-SP, Brazil, $2006-2008$.

\begin{tabular}{|c|c|c|c|c|c|c|c|}
\hline \multirow[t]{2}{*}{ Treatments } & $\mathrm{N}$ & $\mathrm{P}$ & $\mathrm{K}$ & \multirow[t]{2}{*}{$\mathrm{Ca}$} & \multirow[t]{2}{*}{$\mathrm{Mg}$} & \multirow[t]{2}{*}{$S$} & \multirow[t]{2}{*}{$\mathrm{Si}$} \\
\hline & $\overline{\mathrm{g} \mathrm{kg}^{-1}}$ & & & & & & \\
\hline Control & $32.6 a^{1}$ & $3.08 a$ & $30.6 a$ & $16.4 \mathrm{~b}$ & $2.68 a$ & $2.88 \mathrm{a}$ & $2.83 \mathrm{c}$ \\
\hline Liming & $32.7 a$ & $3.17 \mathrm{a}$ & $30.2 a$ & $19.3 a$ & $2.84 a$ & $2.88 a$ & $2.92 b$ \\
\hline Silicate & $32.5 a$ & $3.16 a$ & $30.4 a$ & $19.7 \mathrm{a}$ & $2.90 \mathrm{a}$ & $2.81 \mathrm{a}$ & $3.21 \mathrm{a}$ \\
\hline ANOVA & NS & NS & NS & $* *$ & NS & NS & $* *$ \\
\hline $\operatorname{LSD}(0.05)$ & 174 & 0.29 & 3.93 & 0.52 & 0.29 & 0.25 & 0.07 \\
\hline \multirow[t]{2}{*}{ Treatments } & Dry matter & Population & Pods per plant & Grains per pod & & Mass of 100 grains & Grain yield \\
\hline & $\mathrm{kg} \mathrm{ha}^{-1}$ & $\mathrm{pl} \mathrm{ha}^{-1}$ & Number & & & $\mathrm{g}$ & $\mathrm{kg} \mathrm{ha}^{-1}$ \\
\hline Control & $1257 b$ & $148,500 \mathrm{~b}$ & $3.46 c$ & $3.09 \mathrm{~b}$ & & $23.3 b$ & $458 c$ \\
\hline Liming & 1779a & $181,125 a$ & $4.76 \mathrm{~b}$ & $3.74 a$ & & $26.5 a$ & $699 b$ \\
\hline Silicate & $1807 a$ & $177,750 a$ & $5.10 \mathrm{a}$ & $3.89 a$ & & $27.1 \mathrm{a}$ & $769 a$ \\
\hline ANOVA & $18.0^{* *}$ & $18.4^{* *}$ & $18.0^{* *}$ & $7.3^{* *}$ & & $36.4^{* *}$ & $58.1^{* *}$ \\
\hline $\operatorname{LSD}(0.05)$ & 211 & 12,070 & 0.34 & 0.39 & & 0.97 & 56.3 \\
\hline
\end{tabular}

* and ${ }^{* *}$ significant at a probability level of 5 and $1 \%$, respectively by the F test; NS: non-significant.

1 Means followed by different letters in the column differ statistically by the test $(\mathrm{p}<0.05)$. 
Maize is considered responsive to the application of correction sources. Although tolerance to soil acidity may be variable for each genotype, many studies have demonstrated that soil correction increases maize yield (Caires et al., 2006; Miranda et al., 2005). Oliveira et al. (1997) obtained maximum maize yield in Brazilian 'cerrado' after applying 6.6 $\mathrm{Mg} \mathrm{ha} \mathrm{h}^{-1}$ of lime for acidity correction.

Macronutrient levels in bean leaves (Table 4) were within the appropriate range established by Raij et al. (1997). However, soil correction with both materials only increased $\mathrm{Ca}$ and $\mathrm{Si}$ levels. Si levels were higher after silicate application comparatively to liming, as also observed in soybean (Table 1 ) and white oat (Table 2 ).

Results indicate that Si uptake and translocation in bean plants are improved by silicate application and increasing $\mathrm{pH}$, although bean and soybean are not classified as a Si-accumulating species like oat and maize (Ma and Yamaji, 2006).

Bean was cropped after the third sampling period (18 months after correction materials were applied), when soil fertility was higher. However, dry matter production was low due to bad climate conditions for the bean crop (Table 3). Even under inappropriate environmental conditions, especially low rainfall, liming and silicate application increased dry matter, possibly due to better root development in deeper soil layers and efficiency in water use as a result of higher Si uptake. Although, both correction sources had increased yield components compared to the control, bean yield after silicate application was higher than after liming.

Oliveira et al. (1977) also observed that bean dry matter was increased by liming. Conversely, the authors did not find significant effects on plant population and mass of 100 seeds. In fact, plant population is hardly influenced by $\mathrm{pH}$ changes and seed mass is related to genotype. Still, it is possible to observe beneficial effects of liming of acid soils on initial development and final bean yield (White and Izquierdo, 1991), especially in drought periods (Andrade, 1998).

According to Andrade (1998), unhealthy bean plants produce fewer flowers and pods per plant, directly influencing grain yield. Increasing nutrient availability by liming and silicate application, mainly $\mathrm{Ca}$ and Si levels, certainly improved the source-sink balance and reduced abortion rate of reproductive structures. Deficient mineral nutrition has been reported as one of the causes for bud and pod abortion in bean crop (White and Izquierdo, 1991).

Liming and silicate application increased grain yield by $52.6 \%$ and $67.9 \%$ compared to the control, respectively. Silicate benefits may be related to Si effects on plants under stress even though it is not considered an essential element for plant growth, either physiologically or metabolically (Epstein and Bloom, 2005). Pulz et al. (2008) studied the same materials for acidity correction and reported higher Si levels in potato leaves, which improved plant resistance to water deficit. Similarly, Fageria (2001) found that liming increased bean yield in Brazilian ‘cerrado' under no-till.

\section{Conclusions}

Products from silicate dissociation reach deeper soil layers after 18 months from the application, compared to liming.

Silicate is more efficient than lime as for phosphorus availability and reducing toxic aluminum.

Both correction sources were improved mineral nutrition of all the other crops, mainly $\mathrm{Ca}$ and $\mathrm{Mg}$ levels and agronomical characteristics, reflecting in higher yield.

\section{Acknowledgments}

To FAPESP (The State of São Paulo Research Foundation), for financial support and providing scholarship to the first author.

To CNPq (National Council for Scientific and Technological Development), for an award for excellence in research to the second author.

\section{References}

Alcarde, J.A., Rodella, A.A., 2003. Quality and legislations of fertilizer and acidity correction sources. In: Curi, N., Marques, J.J., Guilherme, L.R.G., Lima, J.M., Lopes, A.S., Álvares, V.H. (Eds.), Topics in Soil Science. SBCS, Viçosa, pp. 291-334 (in Portuguese)

Andrade, M.J.B., 1998. Climate and soil. In: Vieira, C., Paula Jr., T.J., Borém, A. (Eds.), Bean: General Aspects and Crop in Minas Gerais, Brazil. UFV, Viçosa, pp. 83-97 (in Portuguese).

Barcelo, J., Guevara, P., Poschenrieder, C., 1993. Silicon amelioration of aluminium toxicity in teosinte (Zea mays L ssp. Mexicana). Plant and Soil 154, 249-255.

Berni, R.F., Prabhu, A.S., 2003. Relative efficiency of silicon sources on rice leaf blast control. Pesquisa Agropecuária Brasileira 38, 195-201 (in Portuguese).

Caires, E.F., Feldhaus, I.C., Barth, G., Garbuio, F.J., 2002. Lime and gypsum application on the wheat crop. Science in Agriculture 59, 357-364.

Caires, E.F., Garbuio, F.J., Alleoni, L.R.F., Cambri, M.A., 2006. Surface lime application and black oat cover preceding corn and soybean crops under a no-till system. Revista Brasileira de Ciência do Solo 30, 87-98 (in Portuguese).

Carvalho-Pupatto, J.G., Büll, L.T., Crusciol, C.A.C., 2004. Soil chemical attributes, root growth and rice yield according to slag application. Pesquisa Agropecuária Brasileira 39, 1213-1218 (in Portuguese).

Corrêa, J.C., Büll, L.T., Crusciol, C.A.C., Marcelino, R., Mauad, M., 2007. Liming and ion mobility in an Oxisol under surface application of flue dust, aqueous lime, sewage sludge and limestone. Pesquisa Agropecuária Brasileira 42, 1307-1317 (in Portuguese).

Corrêa, J.C., Büll, L.T., Crusciol, C.A.C., Tecchio, M.A., 2008. Surface application of flue dust, aqueous lime, sewage sludge and limestone on soybean crop. Pesquisa Agropecuária Brasileira 43, 1209-1219 (in Portuguese).

Coutinho, F.S., Loss, A., Pereira, M.G., Rodrigues Jr., D.J., Torres, J.L.R., 2010. Aggregate stability and carbon distribution in Oxisol under no-tillage system in Uberaba, Minas Gerais State, Brazil. Comunicata Scientiae 1, 100-105 (in Portuguese).

Epstein, E., Bloom, A.J., 2005. Mineral Nutrition of Plants: Principles and Perspectives. Sinauer Associates, Sunderland . (400 pp.).

Exley, C., 1998. Silicon in life: a bioinorganic solution to bioorganic essentiality. Journal of Inorganic Biochemistry 69, 139-144.

Fageria, N.K., 2001. Effect of liming on upland rice, common bean, corn, and soybean production in cerrado soil. Pesquisa Agropecuária Brasileira 36, 1419-1424 (in Portuguese).

Fageria, N.K., Zimmermann, F.J.P., 1998. Influence of $\mathrm{pH}$ on growth and nutrient uptake by crop species in an Oxisol. Communications in Soil Science and Plant Analysis 29, 2675-2682.

FAO.Food Agriculture Organization of the United Nations, 2006. World reference base for soil resources. World Soil Resources Reports, 103. FAO, Rome . (128 pp.).

Flora, L.P.D., Ernani, P.R., Cassol, P.C., 2007. Cation mobility and acidity decrease in a Haplumbrept due to surface liming combined with potassium fertilizers. Revista Brasileira de Ciência do Solo 31, 1591-1598 (in Portguese).

Franchini, J.C., Hoffmann-Campo, C.B., Torres, E., Miyazawa, M., Pavan, M.A., 2003. Organic composition of green manures during growth and its effect on cation mobilization in an acid Oxisol. Communications in Soil Science and Plant Analysis 34, 2045-2058.

Fuentes, M., González-Gaitano, G., Garcia-Mina, J.M., 2006. The usefulness of UV-visible and fl uorescence sepectroscopies to study the chemical nature of humic substances from soils and composts. Organic Geochemistry 37, 1949-1959.

Goussain, M.M., Moraes, J.C., Carvalho, J.G., Nogueira, N.L., Rossi, M.L., 2002. Effect of silicon application on corn plants upon the biological development of the fall armyworm Spodoptera frugiperda (J.E. Smith) (Lepidoptera: Noctuidae). Neotropical Entomology 31, 305-310 (in Portuguese).

Korndörfer, G.H., Coelho, N.M., Snyder, G.H., Mizutani, C.T., 1999. Evaluation of soil extractants for silicon availability in upland rice. Revista Brasileira de Ciência do Solo 23, 101-106 (in Portuguese).

Ma, J.F., Yamaji, N., 2006. Silicon uptake and accumulation in higher plants. Trends in Plant Science 11, 392-397.

Malavolta, E., Vitti, G.C., Oliveira, S.A., 1997. Evaluation of Plant Nutrition: Principles and Applications. Potafós, Piracicaba . (201 pp. in Portuguese).

McBride, M.B., 1994. Environmental Chemistry of Soils. Oxford University Press, New York . (406 pp.).

Miranda, L.N., Miranda, J.C.C., Rein, T.A., Gomes, A.C., 2005. Lime under no-tillage and conventional planting systems for soybean and corn in Red Latosol (Oxisol). Pesquisa Agropecuária Brasileira 40, 563-572 (in Portuguese).

Oliveira, E.L., Pavan, M.A., 1996. Control of soil acidity in no-tillage system for soybean production. Soil and Tillage Research 38, 47-57.

Oliveira, I.P., Zimmermann, F.J.P., Wilcox, G.E., Fageria, N.K., Costa, J.G.C., 1977. Influence of different phosphorus levels and liming in the bean crop (Phaseolus vulgaris L.). Agrosciencia 12, 55-65 (in Portuguese).

Oliveira, E.L., Parra, M.S., Costa, A., 1997. Maize response to liming in an Oxisol (alic, dark-red latosol). Revista Brasileira de Ciência do Solo 21, 65-70 (in Portuguese).

Prabagar, S., Hodson, M.J., Evans, D.E., 2011. Silicon amelioration of aluminium toxicity and cell death in suspension cultures of Norway spruce (Picea abies (L.) Karst.). Environmental and Experimental Botany 70, 266-276.

Pulz, A.L., Crusciol, C.A.C., Lemos, L.B., Soratto, R.P., 2008. Silicate and limestone effects on potato nutrition, yield and quality under drought stress. Revista Brasileira de Ciência do Solo 32, 1651-1659 (in Portuguese).

Raij, B. van, Cantarella, H., Quaggio, J.A., Furlani, A.M.C., 1997. Recommendations for Fertilization and Liming in the State of São Paulo, Brazil, second ed. IAC, Campinas. (285 p. in Portuguese).

Raij, B. van, Andrade, J.C., Cantarella, H., Quaggio, J.A., 2001. Chemical Analysis for Evaluation of Tropical Soil Fertility. Instituto Agronômico, Campinas . (285 pp. in Portuguese). 
Ramos, L.A., Nolla, A., Korndörfer, G.H., Pereira, H.S., Camargo, M.S., 2006. Reactivity of soil acidity correctives and conditioners in lysimeters. Revista Brasileira de Ciência do Solo 30, 849-857 (in Portuguese).

Rheinheimer, D.S., Santos, E.J.S., Kaminski, J., Bortoluzzi, E.C., Gatiboni, L.C., 2000 Changes in acid soil properties by superficial and incorporated liming on natural pasture. Revista Brasileira de Ciência do Solo 24, 797-805 (in Portuguese).

Rosolem, C.A., Calonego, J.C., Foloni, J.S.S., Garcia, R.A., 2007. Potassium leaching from black oat and pearl millet straw after chemical desiccation. Pesquisa Agropecuária Brasileira 42, 1169-1175 (in Portuguese).

Soratto, R.P., Crusciol, C.A.C., 2008a. Dolomite and phosphogypsum surface application effects on annual crops nutrition and yield. Agronomy Journal 100, 261-270.
Soratto, R.P., Crusciol, C.A.C., 2008b. Nutrition and grain yield of black oat as affected by surface application of lime and phosphogypsum at the establishment of no-tillage system. Revista Brasileira de Ciência do Solo 32, 715-725 (in Portuguese).

Sumner, M.E., Noble, A.D., 2003. Soil acidification: the world story. In: Rengel, Z. (Ed.), Handbook of Soil Acidity. Marcel Dekker, New York, pp. 1-28.

White, J.W., Izquierdo, J., 1991. Physiology of yield potential and stress tolerance. In: van Schoonhoven, A., Voysest, O. (Eds.), Common Beans: Research for Crop Improvement. CAB International, Melkshan, pp. 287-382. 